\title{
Lysine secretion by wild-type Corynebacterium glutamicum triggered by dipeptide uptake
}

\author{
Andreas Erdmann, ${ }^{*}$ Brita Weil and Reinhard Krämer \\ Institut für Biotechnologie 1, Forschungszentrum Jülich, Postfach 1913, D-52425 Jülich, Germany
}

(Received 7 June 1993; revised 12 July 1993; accepted 27 July 1993)

\begin{abstract}
In Corynebacterium glutamicum peptide uptake increases the internal concentration of amino acids and thus triggers amino acid secretion. The peptide uptake system is stimulated by a factor of two in cells grown on pure peptone medium in comparison to peptone media with additional carbon sources. Uptake depends on the protonmotive force and shows a broad substrate spectrum. Peptide uptake is characterized by a $K_{\mathrm{m}}$ of about $230 \mu \mathrm{M}$ and a $V_{\max }$ of $12 \mathrm{nmol} \mathrm{min}^{-1}(\mathrm{mg} \mathrm{dry} \mathrm{wt})^{-1}$ for the peptide lysyl-alanine (Lys-Ala). Lysine secretion in the wild-type of C. glutamicum does not show Michaelis-Menten-type kinetics as reported for the producing strains DG 52-5 and MH 20-22B. The secretion of lysine depends on the composition of the medium in which the cells were grown prior to the initiation of secretion by peptide uptake. The lack of secretion activity when the cells are shifted to peptone medium in the presence of chloramphenicol indicates that protein synthesis is necessary for this regulatory process.
\end{abstract}

\section{Introduction}

Corynebacterium glutamicum and related organisms are widely used for the industrial production of amino acids, especially glutamate and lysine. The producing strains are mostly derived from the wild-type of $C$. glutamicum by classical mutagenesis (Nakayama et al., 1966) and possess an aspartate kinase insensitive to feedback regulation. This enzyme mainly controls lysine biosynthesis in the wild-type by concerted feedback inhibition of lysine plus threonine.

Recently, it was demonstrated that in the producing strain DG 52-5 lysine is secreted together with $2 \mathrm{OH}^{-}$by a cotransport carrier showing Michaelis-Menten-type kinetics (Bröer \& Krämer, 1991 a). Such an export carrier was also expected in the wild-type of $C$. glutamicum but because of the low internal lysine concentration no secretion activity was detected.

In this connection, the question arises of the physiological significance of a lysine export carrier. C. glutamicum can certainly use complex sources, such as proteins and their degradation products, for nutrition. Peptides may fulfil essential amino acid requirements or can serve as the sole nitrogen and/or carbon source. Such processes are well established for Gram-negative bacteria, e.g. E. coli, where three genetically different peptide uptake systems can be found (Higgins \& Gibson,

*Author for correspondence. Tel. $+492461615556 ;$ fax +492461 612710 .
1986). Two of these peptide transport systems belong to the periplasmic or binding-protein transport family (Cowell, 1974). Among Gram-positive bacteria peptide uptake is well characterized in the genus Lactococcus (Smid et al., 1989a,b). Lactococcus lactis possesses a secondary di-tripeptide uptake system dependent on the proton-motive force, which is essential for growth on casein as the sole nitrogen source (Smid et al., 1989b). Recently, a second energy-requiring peptide uptake system transporting oligopeptides was described in L. lactis (Kunji et al., 1993).

Since C. glutamicum is not able to metabolize lysine (Nakayama, 1985), the existence of a specific export carrier may serve to keep the internal lysine concentration at a certain level during growth on complex media. Another possibility of avoiding increased internal lysine concentration would be selection at the level of peptide/amino acid uptake. Thus studies concerning the uptake of lysine-containing peptides should allow the investigation of lysine secretion in the wild-type of C. glutamicum.

\section{Methods}

Growth of organism. The strain used was C. glutamicum ATCC 13032 (wild-type). Cells were grown under aerobic conditions on a rotary shaker (130 r.p.m.) at $30^{\circ} \mathrm{C}$ in a complex medium $\left(\mathrm{g} \mathrm{l}^{-1}\right)$ : peptone, $15 \cdot 6$; yeast extract, $2 \cdot 8 ; \mathrm{NaCl}, 5 \cdot 6$; biotin, $0 \cdot 0002 ; \mathrm{pH} 7 \cdot 0$. The following substances were used as additional carbon sources: $5 \%(\mathrm{w} / \mathrm{v})$ glucose; $100 \mathrm{~mm}$-sodium glutamate; or $100 \mathrm{~mm}$-sodium acetate. In some experiments cells were grown in minimal medium $\left(\mathrm{g}^{-1}\right):\left(\mathrm{NH}_{4}\right)_{2} \mathrm{SO}_{4}, 5$; 
urea, $5 ; \mathrm{KH}_{2} \mathrm{PO}_{4}, 2 ; \mathrm{K}_{2} \mathrm{HPO}_{4}, 2 ; \mathrm{MgSO}_{4} .7 \mathrm{H}_{2} \mathrm{O}, 0 \cdot 25 ; \mathrm{FeSO}_{4} .7 \mathrm{H}_{2} \mathrm{O}$, $0.01 ; \mathrm{MnSO}_{4} .4 \mathrm{H}_{2} \mathrm{O}, 0.01 ; \mathrm{CaCl}_{2} .2 \mathrm{H}_{2} \mathrm{O}, 0.01$; biotin, 0.0002 ; glucose, $50 ; \mathrm{pH} \mathrm{7.0.} \mathrm{Cell} \mathrm{mass} \mathrm{was} \mathrm{determined} \mathrm{by} \mathrm{measuring} \mathrm{the} \mathrm{optical} \mathrm{density}$ (LKB spectrophotometer 4040 Nova Spec II) at $600 \mathrm{~nm}\left(\mathrm{OD}_{600}\right)$; $\mathrm{OD}_{600}=1$ corresponds to $0.32 \mathrm{mg} \mathrm{dry} \mathrm{wt} \mathrm{ml^{-1 }}$.

Determination of peptide uptake and lysine secretion. After growing the cells overnight, $5 \mathrm{ml}$ of the culture were either inoculated into a medium of the same composition $(100 \mathrm{ml})$ or containing a different carbon source. If the carbon source had been changed the cells were washed twice before inoculation by centrifugation $\left(4000\right.$ r.p.m., $4^{\circ} \mathrm{C}$, $10 \mathrm{~min}$ ) in a sterile buffer containing $50 \mathrm{~mm}-\mathrm{MOPS}, 10 \mathrm{~mm}-\mathrm{NaCl}$, $10 \mathrm{~mm}-\mathrm{KCl}, \mathrm{pH} 7.5$. The same washing procedure was used to prepare the cells prior to the peptide uptake experiment after growth for $2.5 \mathrm{~h}$ or $5 \mathrm{~h}$ to the exponential phase.

Peptide uptake and lysine secretion was initiated by adding the cells to prewarmed $\left(25^{\circ} \mathrm{C}\right)$ buffer containing $1 \mathrm{~mm}$-peptide, $10 \mathrm{~mm}$-sodium glutamate or $20 \mathrm{~mm}$-glucose, $50 \mathrm{~mm}-\mathrm{MOPS}, 10 \mathrm{~mm}-\mathrm{NaCl}, 10 \mathrm{~mm}-\mathrm{KCl}$, $\mathrm{pH} 7.5$ at an initial $\mathrm{OD}_{600}$ of 7 . In most experiments, glutamate was used as the carbon source because of possible repression by glucose. In this short-term fermentation, the cells were stirred rapidly by a magnetic stirrer at 500 r.p.m. to ensure a sufficient oxygen supply.

In order to determine the intra- and extracellular concentrations of metabolites (peptide, glutamate, lysine, alanine, glucose) cells and external solution were separated by silicone oil centrifugation (Klingenberg \& Pfaff, 1967). the cell-free supernatant was used directly for metabolite determination by reversed-phase HPLC (HP $1090 \mathrm{M}$, Hewlett-Packard) employing precolumn derivatization with orthophthaldialdehyde reagent (Pierce) and subsequent fluorescence detection. In the case of glucose an enzymic determination was used (Boehringer) as described by Kunst et al. (1983).

Preparation of cell extracts for determination of intracellular amino acids. By means of centrifugation, $100 \mu \mathrm{l}$ of cell suspension was sedimented through $65 \mu \mathrm{l}$ silicone oil (density $1.03 \mathrm{~g} \mathrm{~cm}^{-3}$ ) into $30 \mu \mathrm{l}$ perchloric acid $(20 \%, v / v)$. The tube was cut within the upper layer of oil, and the denatured cells were resuspended in $45 \mu 1$ water together with $10 \mu \mathrm{l}$ of silicone oil with a density of $1.07 \mathrm{~g} \mathrm{~cm}^{-3}$ to absorb membrane material. After breaking up the cells by sonication, neutralizing the extract by addition of $25 \mu \mathrm{l}$ buffer $(5 \mathrm{M}-\mathrm{KOH}, 1 \mathrm{M}-$ triethanolamine) and removing precipitated protein and cell wall material by centrifugation, the extract was used for amino acid analysis as described above (see also Ebbighausen et al., 1989).

Internal ATP concentration. The measurement of intracellular ATP was carried out by direct addition of the cell suspension $(20 \mu \mathrm{l})$ to dimethylsulphoxide $(180 \mu \mathrm{l})$ (Duperray et al., 1992). Samples were further diluted $(1: 5)$ with cold distilled water and kept at $-20^{\circ} \mathrm{C}$ until determination of ATP. This was done by using the firefly luciferase assay (XP 2000, Skan AG) with an internal ATP standard for calibration (Schimz et al., 1981).

Cytoplasmic volume and membrane potential. Determination of cytoplasmic volume is based on comparison of the space occupied by a permeable (water) and an impermeable marker (taurine). The procedure is described in detail elsewhere (Bröer \& Krämer, 1990). Measurement of cells grown in complex media resulted in a value of $1.8 \mu \mathrm{l}(\mathrm{mg} \text { dry } \mathrm{wt})^{-1}$. The distribution of the lipophilic cation $\left[\mathrm{U}-{ }^{14} \mathrm{C}\right]$ tetraphenylphosphonium was measured to determine the membrane potential. Different values of membrane potential were achieved by addition of $10 \mu \mathrm{M}$-valinomycin to cells suspended in solutions with various $\mathrm{K}^{+}$concentrations. The values of membrane potential measured were corrected for nonspecific binding according to the model of Zaritsky et al. (1981). The application of this method for C. glutamicum has been described elsewhere (Ebbighausen et al., 1989).

Calculations. Initial velocities were calculated by linear regression of the first (linear) part of the plot of external concentration $\left(\mu \mathrm{mol} \mathrm{I}^{-1}\right)$ vs. time (min). These values were then recalculated by introducing the initial $\mathrm{OD}_{600}$ to obtain values with units of $\mathrm{nmol} \mathrm{min}^{-1}$ (mg dry wt) ${ }^{-1}$. A negative sign for velocities indicates uptake of the substance specified, a positive (no) sign represents secretion. Values are means \pm 1 SD. The uptake velocity of Lys-Ala in Fig. 3 was determined by calculating the tangent to the curve of extracellular peptide concentration vs. time. These values were recalculated with reference to the actual $\mathrm{OD}_{600}$ and were related to the external peptide concentration measured at the same time in an Eadie-Hofstee plot.

Chemicals. $\left[\mathrm{U}^{-14} \mathrm{C}\right] \mathrm{Tetraphenylphosphonium} \mathrm{bromide}\left(\mathrm{TPP}^{+}\right)$was obtained from NEN/DuPont. Biochemicals were supplied by Boehringer. All other chemicals were of analytical grade and obtained from Merck and Sigma. All peptides were purchased from Bachem (Heidelberg).

\section{Results}

\section{Physiological significance of lysine secretion}

Wild-type cells of $C$. glutamicum grown on complex medium without additional carbon source showed rapid uptake of the peptide lysyl-alanine (Lys-Ala). Subsequently, an increase in internal concentrations of lysine and alanine due to hydrolysis by intracellular peptidase was observed. As a consequence, lysine and alanine were secreted into the medium (Fig. 1). After consumption of the peptide, the internal lysine concentration decreased until it reached its initial value of about $10 \mathrm{~mm}$ (Fig. 1 a). The sum of external and internal lysine and the amount of lysine contained in the peptide was constant over the entire time period. This indicated that no metabolism of lysine took place under these conditions and that internal hydrolysis of the peptide had to be very fast.

In contrast, both the external and internal alanine concentration decreased after consumption of the peptide. Alanine secreted into the medium was afterwards taken up again, and together with the disappearance of internal alanine, this indicated that alanine was almost entirely metabolized (Fig. $1 b$ ).

In order to test whether alanine was sufficient to support growth of C. glutamicum and thus whether the organism is able to utilize peptide as the sole nitrogen source, the experiment shown in Fig. 2 was performed. The organism was able to grow using Lys-Ala as sole nitrogen source and $50 \mathrm{~mm}$-glucose as carbon source, in a buffer containing $50 \mathrm{~mm}-\mathrm{MOPS}, 10 \mathrm{~mm}-\mathrm{NaCl}, 10 \mathrm{~mm}-$ $\mathrm{KCl}$ and biotin $\left(0 \cdot 2 \mathrm{mg} \mathrm{l}^{-1}\right)$. Growth, however, could be achieved only if the cells were grown on complex medium to the exponential phase prior to the peptide utilization experiment. Growth on peptide as sole nitrogen and carbon source was not observed (data not shown). The reason for the inhibition of growth after $20 \mathrm{~h}$ remains unclear since neither the peptide nor the glucose was entirely consumed. High internal concentrations of metabolites (e.g. lysine) might be one factor inhibiting growth. 


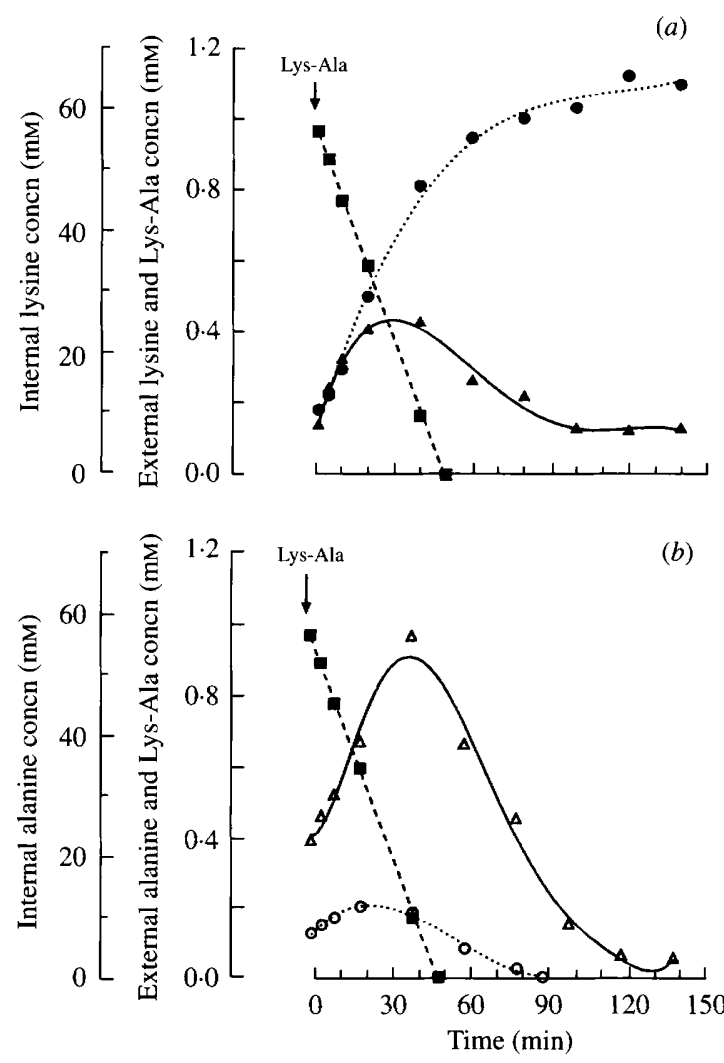

Fig. 1. Uptake of 1 mm-Lys-Ala $(\boldsymbol{\square})$ by $C$. glutamicum grown on complex (peptone) medium and resulting changes in the extra- $(\bullet)$ and intracellular (A) concentration of lysine $(a)$ and extra- $(O)$ and intracellular $(\triangle)$ alanine $(b)$. Transport was measured during shortterm fermentation as described in Methods. MOPS buffer was supplemented by $10 \mathrm{~mm}$-glutamate as carbon source. Each data point represents the mean of six independent experiments.

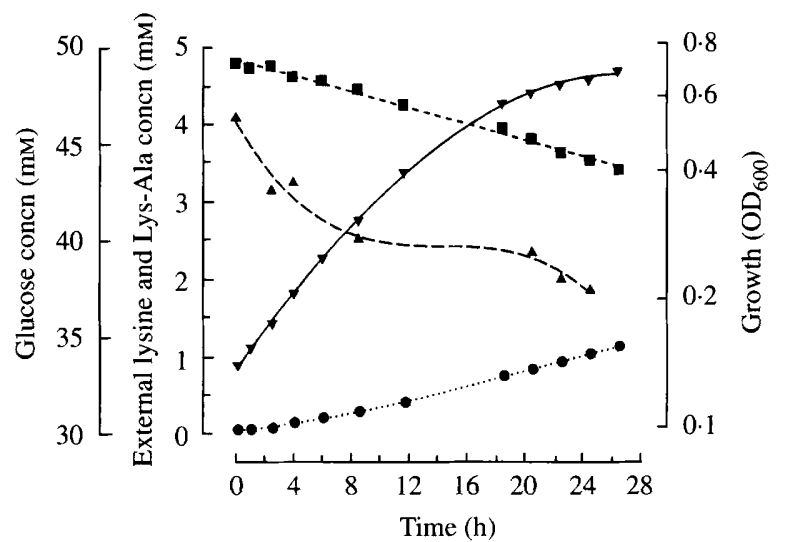

Fig. 2. Growth of C. glutamicum ( $\boldsymbol{\nabla})$ on Lys-Ala as sole nitrogen source. Consumption of Lys-Ala $(\boldsymbol{\nabla})$ and glucose $(\boldsymbol{\Delta})$ (carbon source) are indicated together with secretion of lysine $(\mathbf{O})$.

\section{Characterization of peptide uptake}

Since utilization of the peptide for growth could be observed only if cells were previously grown without glucose, peptide uptake may depend on culture con-

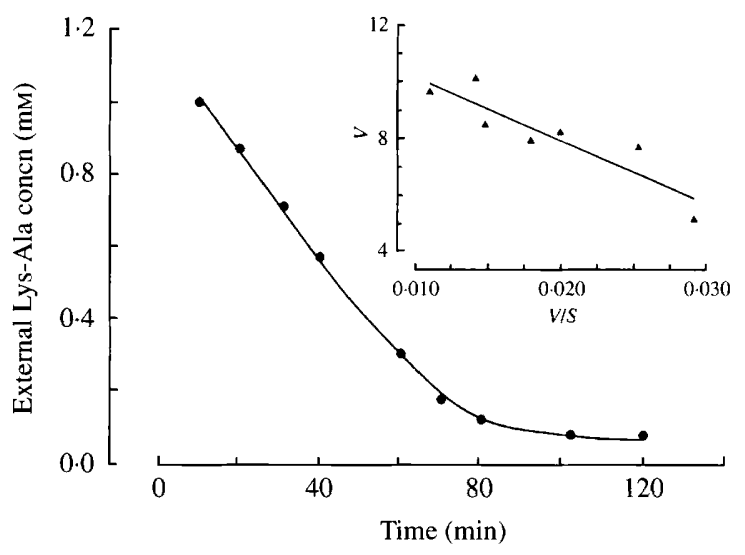

Fig. 3. Uptake of Lys-Ala. Inset: Eadie-Hofstee-plot of uptake velocity, $V\left[\mathrm{nmol} \min ^{-1}(\mathrm{mg} \text { dry wt })^{-1}\right]$ vs. $V /$ external concentration of peptide [nmol (mgdry wt) ${ }^{-1} \min ^{-1} \mu \mathrm{M}^{-1}$ ]. $\quad K_{\mathrm{m}}(230 \mu \mathrm{M})$ and $V_{\max }$

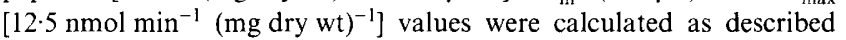
in Methods. Each data point represents the mean of two independent experiments.

ditions. Any addition, independent of the carbon source (100 mM-glutamate, $100 \mathrm{~mm}$-acetate or $5 \%, \mathrm{w} / \mathrm{v}$, glucose), to the complex (peptone) medium reduced the initial velocity of peptide uptake by about $50 \%$ compared to media without any addition [initial velocity of

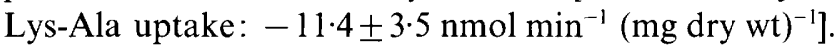
The lowest transport activity was found in cells grown in the minimal medium : $4 \cdot 0 \pm 0 \cdot 8 \mathrm{nmol} \min ^{-1}(\mathrm{mg} \text { dry wt })^{-1}$.

Specificity. In order to increase the internal lysine concentration effectively the specificity of the peptide uptake system was investigated. The decrease of extracellular peptide with time occurred in all experiments similar to that shown in Fig. 1(a). Besides the uptake of Lys-Ala, four other lysine-containing peptides were used : Ile-Lys, Lys-Ile, Lys-Glu and Lys-Lys-Lys. The initial

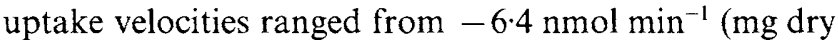
$\mathrm{wt})^{-1}$ for Lys-Lys-Lys to $-2.7 \mathrm{nmol} \mathrm{min}^{-1}$ (mg dry wt) ${ }^{-1}$ for Lys-Glu. Additionally, the transport of five other alanine-, valine-, isoleucine- or leucine-containing peptides was measured ( $\mathrm{S}$. Zittrich, personal communication). Of the ten peptides investigated, Lys-Ala was taken up most rapidly (see above) whereas Ile-Val showed the lowest transport velocity, $1.2 \mathrm{nmol} \mathrm{min}{ }^{-1}$ (mg dry wt $)^{-1}$. The absolute values of peptide uptake are in the range reported in the literature for various organisms (Payne \& Gilvarg, 1978; Nisbet \& Payne, 1982; Smid et al., 1989a; Smid, 1991).

Affinity. The $V_{\max }$ and $K_{\mathrm{m}}$ of peptide uptake were calculated from the decrease in the extracellular concentration of Lys-Ala (Fig. 3). Due to the limited sensitivity of non-radioactive uptake measurements of peptides (HPLC), these values were determined using the deviations from linearity of uptake at low peptide 


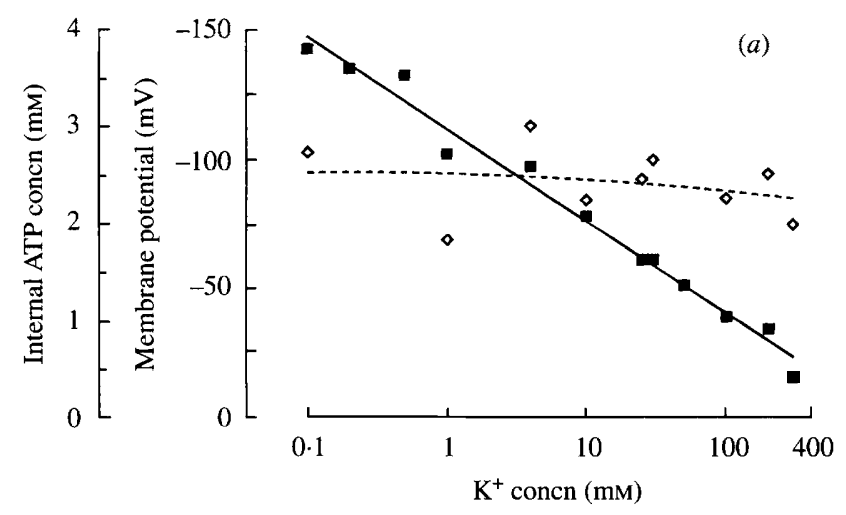

(b)

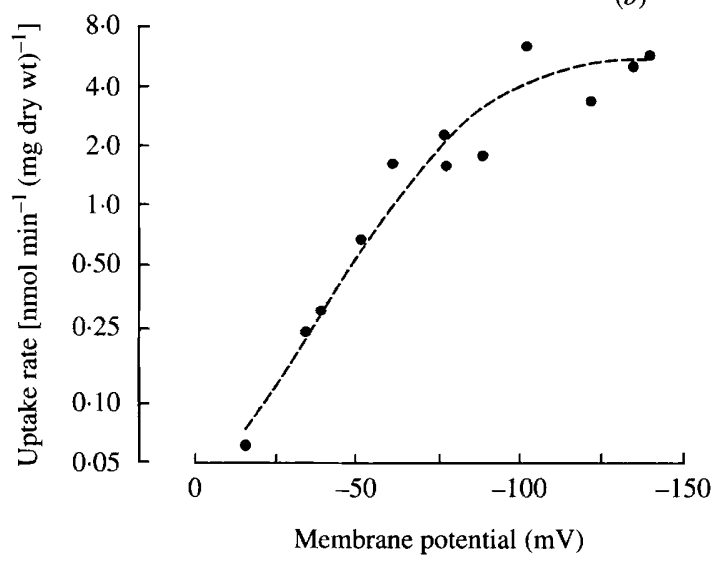

Fig. 4. (a) Dependence of membrane potential ( $\square$ ) measured by TPP ${ }^{+}$ distribution and internal ATP concentration $(\diamond)$ on external $\mathrm{K}^{+}$ concentration in the presence of $20 \mu \mathrm{M}$-valicomycin. (b) Relation between membrane potential obtained as described in $(a)$ and uptake velocity of Lys-Ala. Peptide uptake was measured during short-term fermentation in MOPS buffer supplemented by $5 \%(\mathrm{w} / \mathrm{v})$ glucose.

concentrations (see Methods). The $V_{\max }$ was calculated to be $12.53 \pm 0.96 \mathrm{nmol} \mathrm{min}^{-1}$ (mg dry wt) ${ }^{-1}$ for Lys-Ala and the $K_{\mathrm{m}}$ value was $230 \pm 53 \mu \mathrm{M}$. This peptide was used for further experiments.

Mechanism. In order to obtain insight into the mechanism of peptide uptake in C. glutamicum, the influence of ATP and membrane potential on peptide uptake was tested. The protonophore CCCP (carbonyl cyanide $m$-chlorophenylhydrazone) inhibited uptake of Lys-Ala by $78 \%$ at a concentration of $15 \mu \mathrm{M}$ and by $83 \%$ at $200 \mu \mathrm{M}$. The strongest inhibition $(95 \%)$ was obtained by the combination of $2 \mu \mathrm{M}$-valinomycin and $0.2 \mu \mathrm{M}$-nigericin in the presence of $300 \mathrm{mM}-\mathrm{KCl}$. Since under such conditions (buffer supplemented by $5 \%$ glucose) the ATP concentration was also decreased in comparison to the control without ionophore, the influence of these two parameters on peptide uptake was investigated in more detail. Fig. 4(a) shows the dependence of the membrane potential on the external $\mathrm{K}^{+}$ concentration in the presence of $20 \mu \mathrm{M}$-valinomycin. Although being somewhat reduced, the ATP concentration does not depend on the external $\mathrm{K}^{+}$concentration. The linear relation between membrane potential and the logarithm of the uptake rate (Fig. $4 b$ ) serves as additional evidence for the mechanism of secondary transport, at least for the peptide Lys-Ala.

\section{Characterization of peptide-triggered lysine secretion}

Peptide uptake and subsequent hydrolysis increased the internal lysine concentration in the wild-type of C. glutamicum (Fig. 1a). As a consequence lysine was secreted. This was true of all conditions investigated. The initial efflux velocity was dependent on the composition of the medium in which the cells were grown prior to peptide uptake (Fig. 5a). Growth in peptone medium without additional carbon source resulted in a velocity of $6.8 \pm 0.4 \mathrm{nmol} \mathrm{min}^{-1}$ (mg dry wt) $)^{-1}(n=6)$. This value was at least twice as high as the values found for media with an additional carbon source $(n \geqslant 3)$. These were: in peptone with $5 \%(\mathrm{w} / \mathrm{v})$ glucose, $1.6 \pm 0.6 \mathrm{nmol} \mathrm{\textrm {min } ^ { - 1 }}$ (mg dry wt) ${ }^{-1}$; in peptone with $100 \mathrm{~mm}$-acetate, $2.5 \pm 1.9$ nmol $\mathrm{min}^{-1}$ (mg dry wt $)^{-1}$; in peptone with $100 \mathrm{~mm}$ -

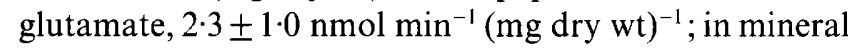
medium with $5 \%(\mathrm{w} / \mathrm{v})$ glucose, $3.0 \pm 0.4 \mathrm{nmol} \mathrm{min}^{-1}$ $(\mathrm{mg} \text { dry } w \mathrm{t})^{-1}$. Although the values of initial efflux velocity obtained after growth in media with various additional carbon sources were not significantly different, Fig. $5(b)$ shows that further changes in the transport process had to be taken into account. After consumption of the peptide Lys-Ala (indicated by dotted arrows), the ability to lower the internal lysine concentration differed in the various kinds of cells. Cells grown in peptone medium with $5 \%(\mathrm{w} / \mathrm{v})$ glucose maintained a high internal lysine concentration (Fig. $5 b$ ) for at least $6 \mathrm{~h}$ (data not shown). The results of Fig. 5 indicate that the initial velocity of secretion is not sufficient to characterize these transport phenomena, but the time course of internal lysine concentration also had to be studied. Since the data of Fig. 5 could be explained by a regulatory process, we investigated whether this process could be observed by changing the carbon source of the media for a short period before testing for peptide uptake.

After growth overnight in peptone medium, with or without $5 \%(\mathrm{w} / \mathrm{v})$ glucose, the cells were transferred to peptone medium without additional carbon source for $2 \cdot 5 \mathrm{~h}$. Fig. 6 shows that cells grown solely in peptone medium exhibited the highest initial velocity of lysine secretion and a relatively small and transient increase of the internal lysine. In comparison to the data in Fig. 5, cells grown overnight in the presence of glucose could be stimulated to secrete lysine by subsequent growth in pure 

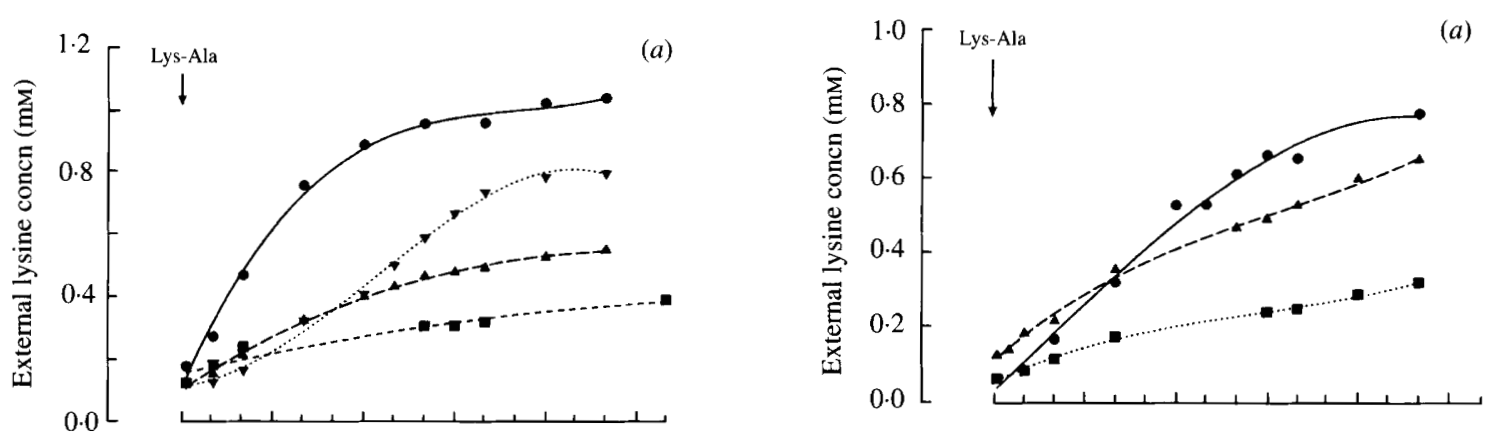

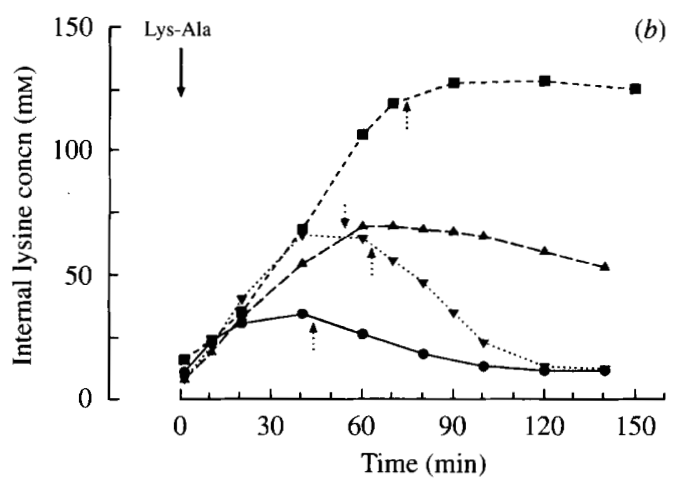

Fig. 5

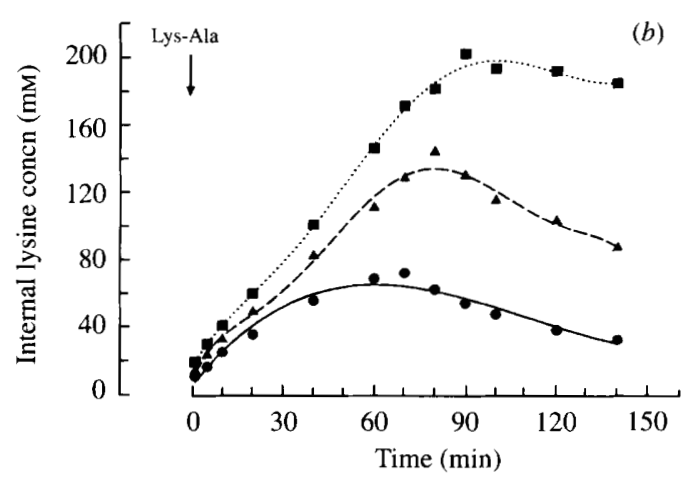

Fig. 6

Fig. 5. Lysine secretion ( $a$, external conen; $b$, internal concn) by $C$. glutamicum triggered by dipeptide uptake. Cells were grown on complex (peptone) medium ( $)$, on peptone with $100 \mathrm{~mm}$-glutamate $(\boldsymbol{\nabla})$, on peptone with $100 \mathrm{~mm}$-acetate $(\boldsymbol{\Delta})$, and on peptone with $5 \%$ glucose $(\boldsymbol{\square})$. Dotted arrows in $(b)$ indicate the point of complete peptide consumption. Peptide uptake was followed during shortterm fermentation in MOPS buffer supplemented by $10 \mathrm{~mm}$-glutamate. Each data point represents the mean of at least three independent experiments.

Fig. 6. Induction of lysine secretion ( $a$, external concn; $b$, internal concn) in C. glutamicum by changing the growth medium. Cells were either grown on peptone medium alone (๑) during the whole period or the growth medium was shifted from peptone with $5 \%$ glucose (overnight) to peptone alone for $2.5 \mathrm{~h}(\mathbf{\Delta})$. $\mathbf{\square}$. Growth medium changed as above but $50 \mu \mathrm{g}$ chloramphenicol $\mathrm{ml}^{-1}$ was added to the peptone medium without glucose. Peptide uptake was followed during short-term fermentation in MOPS buffer supplemented by 20 mM-glucose.

peptone medium for $2.5 \mathrm{~h}$. The secretion activity in this case did not reach the maximal value. The observed stimulation could be prevented in these cells by adding the protein synthesis inhibitor chloramphenicol $(50 \mu \mathrm{g}$ $\mathrm{ml}^{-1}$ ) after shifting to peptone medium. In the experiments of Fig. 6, peptide uptake was investigated in a buffer supplemented with glucose, since the uptake of glutamate is also dependent on the medium composition (Krämer et al., 1990).

In order to identify a possible regulatory compound responsible for the observed stimulation, the internal amino acid composition of cells grown in peptone medium with or without $5 \%(\mathrm{w} / \mathrm{v})$ glucose was analysed. We detected significant differences in the concentrations of internal amino acids (e.g. glutamate, glycine, alanine, serine, arginine). In particular, the increased concentration of lysine $(14.4 \mathrm{~mm})$ in medium without glucose in comparison to medium with glucose $(8.6 \mathrm{mM})$ should be considered.

\section{Discussion}

A specific lysine secretion system was previously characterized in producing strains of C. glutamicum (Bröer \& Krämer, $1991 a, b$ ). It was suggested that this secretion carrier serves to regulate the internal lysine concentration under conditions where complex substances are the main nutrients. Uptake of peptides and consecutive efflux of amino acids has also been shown to occur in lactococci (Perry \& Abraham, 1979; Nisbet \& Payne, 1982). Possible interference by the presence of extracellular peptidases, as discussed in connection with peptide utilization (Smid et al., 1989a), was ruled out for C. glutamicum. After drastic reduction of the membrane potential by CCCP or valinomycin in the presence of high external $\mathrm{K}^{+}$concentrations the external peptide concentration remained more or less constant for a reasonable period of time (data not shown). Since the uptake of lysine in C. glutamicum is very low (Bröer \& 
Krämer, 1990) this flux also did not need to be considered as a possible artefact here.

Using the dipeptide Lys-Ala, we demonstrated that C. glutamicum was able to grow on complex nutrients as the sole nitrogen source (Fig. 2). Similar results were reported by Brecher et al. (1992) concerning the growth of $E$. coli on degradation products of chymotrypsin, where the peptides support growth most effectively as the nitrogen source and less as the carbon source. Utilization of peptides by $C$. glutamicum did occur even if lysine, which cannot be metabolized (Nakayama, 1985), was present in the peptide. The theoretical possibility of avoiding an increase in internal lysine by selection at the level of peptide uptake did not take place. Therefore, it is reasonable to conclude that secretion carriers serve to control the amino acid pool under physiological conditions of growth on complex nutrients.

Since we found that $C$. glutamicum utilizes peptides only in the case of growth on complex medium without glucose, an influence of the medium composition on peptide uptake and/or lysine secretion had to be considered. In E. coli the presence of external amino acids has no influence on the uptake of peptides containing the same amino acids (Payne \& Bell, 1977). E. coli possesses three genetically different peptide uptake systems (Hiles et al., 1987; Abouhamad et al., 1991), of which only one, the tripeptide permease (Tpp), can be stimulated by external leucine as well as by anaerobiosis. C. glutamicum showed the highest peptide uptake rate when cells were grown on proteins and their degradation products only (peptone medium). The addition of other carbon sources reduced the uptake velocity by about $50 \%$. Since this phenomenon was independent of the nature of the carbon source (amino acid, sugar or organic acid) it could be assumed that external peptides themselves were the reason for the observed differences. Specificity or affinity (Fig. 3) of peptide uptake by C. glutamicum was comparable to other systems described in the literature (Payne \& Bell, 1979; Nisbet \& Payne, 1982; Smid, 1991; see also Results). The existence of more than one peptide uptake system in C. glutamicum cannot be excluded by the results obtained, although the results of Fig. 3 indicate that the dipeptide Lys-Ala is taken up by one kinetically distinguishable transport system.

Peptide uptake systems were characterized as being binding-protein-dependent in Gram-negative as well as in Gram-positive bacteria (Van Boven \& Konings, 1987; Abouhamad et al., 1991; Kunji et al., 1993). For Grampositive bacteria the existence of secondary transport systems for peptides dependent on the proton-motive force as the driving force has also been reported (Payne \& Nisbet, 1981; Smid et al., 1989a). Data presented in Fig. 4, showing a linear relation between the logarithm of peptide uptake rate and membrane potential, demonstrate that the observed peptide uptake in $C$. glutamicum depended on the proton-motive force rather than on ATP. The uptake rate under 'saturation' conditions at very high values of the membrane potential corresponds to initial uptake rates measured under similar conditions (MOPS buffer supplemented by glucose) without the addition of valinomycin. Such a 'saturation' effect was also described for the membrane-potentialdependent secretion of lysine in C. glutamicum (Bröer \& Krämer, $1991 b$ ). The concomitant inhibition of lysine secretion under conditions of reduced membrane potential (data not shown) revealed that characteristics of lysine export in the wild-type of $C$. glutamicum are comparable to those shown for producing strains (Bröer \& Krämer, $1991 b$ ).

In contrast to lysine-producing strains of $C$. glutamicum, which are thought to differ from the wild-type in having a feedback-insensitive aspartate kinase (Menkel et al., 1989), no effective lysine secretion could be achieved for the wild-type by growth on glucosecontaining minimal media (Bröer et al., 1993). Therefore we used the procedure of peptide feeding to increase the internal lysine concentration in the wild-type. The results shown in Fig. $1(a)$ and $5(b)$ indicate that the concentration can be raised to at least $25 \mathrm{~mm}$ under all conditions investigated. This increase did not cause an appropriate secretion of lysine as would be expected from Michaelis-Menten-type kinetics, despite the fact that the values of internal lysine found after peptide uptake exceeded the internal $K_{\mathrm{m}}$ of $20 \mathrm{~mm}$ calculated for the producing strain DG 52-5 (Bröer \& Krämer, 1991 a). Non-Michaelis-Menten-type kinetics was also observed for a recombinant strain of $C$. glutamicum where the wild-type aspartate kinase was replaced by a feedbackinsensitive one, leading to elevated internal lysine concentrations (Bröer et al., 1993). We conclude that additional regulatory mechanisms have to be taken into account.

The results concerning dipeptide-triggered lysine secretion shown in Fig. 5 argue for a dependence of lysine secretion activity on the composition of the growth media. The initial velocity of lysine secretion was about three times higher in cells grown in peptone medium as compared to those grown with additional carbon source. The different behaviour of lysine secretion can be interpreted as a regulatory (possibly induction/ derepression) phenomenon. In order to identify an appropriate effector, the internal amino acid composition was investigated in cells grown on peptone (highest secretion rate) and on peptone with glucose (lowest secretion rate). It was possible to detect significant differences between cells grown in these two media. As is known for various inducible amino acid uptake systems, 
the presence or absence of the amino acid to be transported is responsible for increased transport activity (Ring, 1969; Miller \& Rodwell, 1971; Quay \& Oxender, 1976; Steffes et al., 1992). By analogy to this and to the induction of the uptake system for branched-chain amino acids in C. glutamicum (Boles et al., 1993), it might be assumed that the high internal lysine concentration found in cells grown in the absence of glucose (see results) serves as a stimulating effector for the regulation of lysine secretion. Additionally, the presence of glucose may repress the transport, as reported for glutamate uptake in C. glutamicum (Krämer et al., 1990).

Both phenomena, induction and derepression, require de novo synthesis of protein. Thus dipeptide-triggered lysine secretion was investigated after inhibition of protein synthesis by chloramphenicol. Since the uptake of Lys-Ala was almost unchanged by this treatment (data not shown) the decrease in the secretion rate in the presence of chloramphenicol (Fig. 6a) must be caused by preventing the observed regulatory process(es) by inhibition of protein synthesis. Significant differences in the internal lysine concentration were not found in cells grown in the presence or absence of chloramphenicol (data not shown). The possibility that lysine secretion is mediated by a carrier that is cooperatively controlled by lysine and/or other unknown effectors cannot be entirely excluded by these experiments. At the molecular level, the mechanism of reduction of lysine secretion by the addition of external carbon source still remains to be studied.

In the wild-type of $C$. glutamicum lysine is secreted by a specific carrier after increasing the internal pool by dipeptide uptake. The lysine secretion system is presumably stimulated at the expression level by high internal lysine (and/or by other amino acid) concentrations. In contrast to lysine secretion in producing strains (Bröer \& Krämer, 1991 a), Michaelis-Mententype kinetics could not be observed. A similar result was reported by Bröer et al. (1993) for a recombinant strain differing from the wild-type only in its aspartate kinase. Therefore, additional regulatory processes at the activity level concerning the secretion rate have to be taken into account. In summary, the observed regulatory processes of lysine secretion provide the wild-type of $C$. glutamicum with fast and sensitive response mechanisms to environmental changes.

We wish to thank Professor H. Sahm for continuous support and for helpful discussions and suggestions. This work is part of a joint project with Degussa AG and is supported by the Fonds der Chemischen Industrie.

\section{References}

Abouhamad, W. N., Manson, M., Gibson, M. M. \& Higgins, C. F. (1991). Peptide transport and chemotaxis in Escherichia coli and
Salmonella typhimurium: characterization of the dipeptide permease (Dpp). Molecular Microbiology 5, 1035-1047.

Boles, E., Ebbighausen, H., Eikmanns, B. \& Krämer, R. (1993). Unusual regulation of the uptake system for branched-chain amino acids in Corynebacterium glutamicum. Archives of Microbiology 159 , 147-152.

Brecher, A. S., Moehlman, T. A. \& HanN, W. D. (1992). Utilization of chymotrypsin as sole carbon and (or) nitrogen source by Escherichia coli. Canadian Journal of Microbiology 38, 290-295.

BRöER, S. \& KRÄMER, R. (1990). Uptake and exchange of lysine in Corynebacterium glutamicum. Journal of Bacteriology 172, $7241-7248$.

BRÖER, S. \& KRÄMER, R. (1991 a). Lysine excretion by Corynebacterium glutamicum. I. Identification of a specific carrier system. European Journal of Biochemistry 202, 131-135.

BRÖER, S. \& KRÄMER, R. (1991b). Lysine excretion by Corynebacterium glutamicum. II. Energetics and mechanism of the transport system. European Journal of Biochemistry 202, 136-142.

BröER, S., EgGeling, L. \& KRÄMER, R. (1993). Strains of Corynebacterium glutamicum differing in lysine productivity possess different lysine excretion systems. Applied and Environmental Microbiology 59, 316-321.

Cowell, J. L. (1974). Energetics of glycylglycine transport in Escherichia coli. Journal of Bacteriology 120, 139-146.

Duperray, F., Jezequel, D., Ghazi, A., Letellier, L. \& Shechter, E. (1992). Excretion of glutamate from Corynebacterium glutamicum triggered by amine surfactants. Biochimica et Biophysica Acta 1103, 250-258.

Ebbighausen, H., Weil, B. \& Krämer, R. (1989). Transport of branched-chain amino acids in Corynebacterium glutamicum. Archives of Microbiology 151, 238-244.

Higgins, C. F. \& Gibson, M. M. (1986). Peptide transport in bacteria. Methods in Enzymology 125, 365-377.

Hiles, I. D., Powell, L. M. \& Higgins, C. F. (1987). Peptide transport in Salmonella typhimurium: molecular cloning and characterization of the oligopeptide permease genes. Molecular and General Genetics 206, 101-109.

Klingenberg, M. \& Pfaff, E. (1967). Means of terminating reactions. Methods in Enzymology 10, 680-684.

Krämer, R., Lambert, C., Hoischen, C. \& Ebbighausen, H. (1990). Uptake of glutamate in Corynebacterium glutamicum. I. Kinetic properties and regulation by internal $\mathrm{pH}$ and potassium. European Journal of Biochemistry 194, 929-935.

Kunj,, E. R. S., Smid, E. J., Plapp, R., Poolman, B. \& Konings, W. N. (1993). Di-tripeptides and oligopeptides are taken up via distinct transport mechanisms in Lactococcus lactis. Journal of Bacteriology 175, 2052-2059.

Kunst, A., DRAEGER, B. \& ZiEgENHORN, J. (1983). UV-methods with hexokinase and glucose-6-phosphate dehydrogenase. In Methods of Enzymatic Analysis, vol. 6, pp. 163-172. Basel: Verlag Chemie Weinheim

Menkel, E., Thierbach, G., Eggeling, L. \& Sahm, H. (1989). Influence of increased aspartate availability on lysine formation by a recombinant strain of Corynebacterium glutamicum and utilization of fumarate. Applied and Environmental Microbiology 55, 684-688.

Miller, D. L. \& Rodwell, V. W. (1971). Metabolism of basic amino acids in Pseudomonas putida: properties of the inducible lysine transport system. Journal of Biological Chemistry 246, 1765-1771.

NaKaYAMa, K. (1985). Lysine. In Comprehensive Biotechnology, vol. 3. Edited by M. Moo-Young. Oxford: Pergamon Press.

Nakayama, K., Tanaka, H., Hagino, H. \& Kinoshita, H. (1966). Studies on lysine fermentation. V. Concerted feedback inhibition on aspartic semialdehyde-pyruvate condensation in Micrococcus glutamicus. Agricultural and Biological Chemistry 30, 611-616.

Nisbet, T. M. \& Payne, J. W. (1982). The characteristics of peptide uptake in Streptococcus faecalis: studies on the transport of natural peptides and antibacterial phosphonopeptides. Journal of General Microbiology 128, 1357-1364.

PAYNe, J. W. \& Bell, G. (1977). Substrate interaction during transport of amino acids and peptides by Escherichia coli: relevance to regulation of peptide uptake. FEMS Microbiology Letters 2, 301-304. 
PAyne, J. W. \& Bell, G. (1979). Direct determination of the properties of peptide transport systems in Escherichia coli, using a fluorescent labelling procedure. Journal of Bacteriology 137, 447-455.

PAYNE, J. W. \& Gilvarg, C. (1978). Transport of peptides in bacteria, In Bacterial Transport, pp. 325-383. Edited by B. P. Rosen. New York: Marcel Dekker.

PAyNe, J. W. \& Nisbet, T. M. (1981). Continuous monitoring of substrate uptake by microorganisms using fluorescamine: application to peptide transport by Saccharomyces cerevisiae and Streptococcus faecalis. Journal of Applied Biochemistry 3, 447-458.

Perry, D. \& Abraham, E. P. (1979). Transport and metabolism of bacilysin and other peptides by suspensions of Staphylococcus aureus. Journal of General Microbiology 115, 213-221.

QuAY, S. C. \& OXENDER, D. L. (1976). Regulation of branched-chain amino acid transport in Escherichia coli. Journal of Bacteriology 127, 1225-1238.

RING, K. (1969). Die Induktion des aktiven Transportes neutraler Aminosäuren bei Streptomyces hydrogenans. Biochimica et Biophysica Acta 183, 375-393.

Schimz, K. L., RÜtten, B. \& Tretter, M. (1981). Determination of adenosine nucleotides with luciferin/luciferase from crude firefly lantern extract on a bioluminescence analyser. Advances in Biotechnology 1, 457-462.

SMID, E. J. (1991). Physiological implications of peptide transport in lactococci. PhD thesis, University of Groningen, The Netherlands.

Smid, E. J., Driessen, A. J. M. \& Konings, W. N. (1989a). Mechanism and energetics of dipeptide transport in membrane vesicles of Lactococcus lactis. Journal of Bacteriology 171, 292-298.

Smid, E. J., Plapp, R. \& Konings, W. N. (1989 b). Peptide uptake is essential for growth of Lactococcus lactis on the milk protein casein. Journal of Bacteriology 171, 6135-6140.

Steffes, C., Ellis, J., Wu, J. \& Rosen, B. P. (1992). The lys $P$ gene encodes the lysine-specific permease. Journal of Bacteriology 174, 3242-3249.

Van Boven, A. \& Konings, W. N. (1987). A phosphate-bond-driven dipeptide transport system in Streptococcus cremoris is regulated by the internal pH. Applied and Environmental Microbiology 53, 2897-2902.

Zaritsky, A., Kihara, M. \& MaCnab, R. M. (1981). Measurement of membrane potential in Bacillus subtilis: a comparison of lipophilic cations, rubidium ion, and a cyanine dye as probes. Journal of Membrane Biology 63, 215-231. 